\section{Pengembangan Bahan Ajar untuk Mata Kuliah Kriya Batik}

\author{
Hasnawati ${ }^{1}$ \\ Fakultas Seni dan Desain \\ Universitas Negeri Makassar \\ Email: hasnawatidaengngana78@gmail.com \\ http://ojs.unm.ac.id/index.php/Insani/index
}

Abstrak. Penelitian ini bertujuan untuk merancang bahan ajar pembelajaran batik untuk mahasiswa di Program Studi Pendidikan Seni Rupa. Jenis penelitian ini merupakan penelitian pengembangan, yaitu perancangan bahan ajar pembelajaran batik. Alur penelitian yang dilakukan adalah menganalisis kebutuhan, pengembangan strategi pembelajaran, pengembangan produk, bahan ajar tahap awal, evaluasi bahan ajar, bahan ajar tahap akhir. Teknik pengumpulan data dilakukan dengan teknik observasi, wawancara, angket, dan dokumentasi. Analisis data dilakukan dengan teknik analisis deskriptif kualitatif. Hasil penelitian ini diketahui bahwa Pengembangan bahan ajar pada mata kuliah Seni Kriya Tekstil melalui beberapa tahap, yaitu: tahap analisis kebutuhan melalui dua tahap yaitu tahap studi lapangan dan studi literatur, tahap pengembangan strategi pembelajaran melalui pengkajian rencana program semester, tahap pengembangaan bahan ajar yaitu mengumpulkan materi-materi terkait dengan seni kriya tesktil, dan realisasi bahan ajar tahap awal, dan disesuaikan dengan Rencana Program Semester (RPS) yang telah dikembangkan sebelumnya. Bahan ajar ini belum dilakukan tahap eavaluasi ahli baik ahli materi, ahli media maupun ujicoba.

Kata Kunci: Bahan Pembelaran, Kriya Tekstil, Batik

\section{INDONESIAN JOURNAL OF EDUCATIONAL STUDIES (IJES)}

\section{E-ISSN: 2621-6744 P-ISSN: 2621-6736}

Submitted: August 22 ${ }^{\text {nd }} 2018$

Accepted : October $3^{\text {rd }} 2018$

Abstract. This study aims to design batik learning teaching materials for students in the Fine Arts Education Study Program. This type of research is development research, which is the design of batik learning teaching materials. Data collection techniques were carried out by observation, interviews, questionnaires, and documentation. Data analysis was performed with qualitative descriptive analysis techniques. The results of this study are known that the development of teaching materials in the Textile Craft Art subject through several stages, namely: the needs analysis phase through two stages, namely the field study and literature studies, the development phase of learning strategies through the semester program plan assessment, the development of teaching materials the materials related to technical skills, and the realization of the initial teaching materials, and adapted to the Semester Program Plan (RPS) that had been developed previously. This teaching material has not yet been carried out by the expert eavaluation stage, both material experts, media experts and experiments. 


\section{PENDAHULUAN}

Peningkatan mutu pendidikan merupakan tugas kita semua. Dunia pendidikan mempunyai peranan yang sangat penting dalam meningkatkan mutu bangsa Indonesia. Berbagai hal yang telah dilakukan pemerintah dalam peningkatan kualitas pendidikan adalah dengan menggalakan buta aksara, adanya inovasiinovasi dalam pembelajaran, baik di bidang metode, pendekatan, maupun media yang digunakan dalam pembelajaran. Selanjutnya, salah satu upaya untuk memperbaiki sistem dan meningkatkan mutu pendidikan di Indonesia adalah melalui berbagai kegiatan akademik dengan melakukan penyempurnaan kurikulum, peningkatan kualifikasi melalui studi lanjut, peningkatan manajemen pendidikan, peningkatan sarana dan prasarana, peningkatan mutu dosen melalui kegiatan penelitian dan pelatihan, serta pengadaan buku ajar dan buku referensi pada setiap mata kuliah.

Berkaitan dengan hal tersebut, salah satu permasalahan yang ada pada dunia pendidikan di Perguruan Tinggi adalah masih terbatasnya bahan ajar atau referensi perkuliahan yang sesuai dengan karakter mata kuliah dan mahasiswa. Bahkan, pengadaan bahan ajar di setiap mata kuliah, khususnya pada mata kuliah kriya Tekstil (Batik), belum pernah dilakukan khususnya di Program Studi Pendidikan Seni Rupa FSD UNM. Referensi yang digunakan oleh mahasiswa masih sangat terbatas, sehingga referensi untuk membuat karya kriya tekstil juga terbatas, mahasiswa hanya mengetahui konsep batik, alat dan bahan yang digunakan dalam pembuatan karya tekstil (batik).

Hasil penelitian yang telah dilakukan oleh mahasiswa atas nama Muhammad Arif angkatan 2011 pada tahun 2017, maka dapat diketahui bahwa permasalahan yang diteliti oleh mahasiswa tersebut adalah tentang kreativitas mahasiswa Program Studi Pendidikan Seni Rupa Fakultas Seni dan Desain Universitas Negeri Makassar Angkatan 2015 dalam membuat desain motif batik. Hasil penelitian mahasiswa tersebut dapat ketahui bahwa mahasiswa masih kurang kreatif dalam membuat desain motif batik. Salah satu penyebab kurangnya kreativitas mahasiswa angkatan 2015 dalam membuat desain motif batik adalah karena kurangnya referensi tentang batik. Berdasarkan uraian di atas, maka tujuan umum penelitian ini adalah untuk memecahkan permasalahan tentang rendahnya kreativitas mahasiswa dalam membuat desain motif batik. Secara khusus penelitian ini bertujuan untuk merancang bahan ajar pada pembelajaran kriya tekstil (batik) yang untuk mahasiswa di Program Studi Pendidikan Seni Rupa.

\section{KAJIAN TENTANG BAHAN AJAR}

Syaiful Bahri Djamarah (1997: 17) berpendapat bahwa bahan adalah substansi yang akan disampaikan dalam proses interaksi pembelajaran. Bahan pelajaran adalah unsur inti dalam kegiatan interaksi pembelajaran, karena itu harus diupayakan untuk dikuasai oleh peserta didik. Suharsimi Arikunto (1990) mengatakan bahwa bahan pembelajaran merupakan unsur inti yang ada dalam kegiatan belajar mengajar, karena memang bahan pelajaran itulah yang diupayakan untuk dikuasai oleh anak didik. 
Selanjutnya, Ella Yulaelawati (2004: 133) menjelaskan bahwa sumber belajar yang utama bagi pendidik adalah sarana cetak, seperti buku, brosur, majalah, surat kabar, poster, lembar informasi lepas, naskah brosur, peta, foto, dan lingkungan sekitar. Pembelajaran yang baik memerlukan sebanyak mungkin sumber belajar untuk memperkaya pengalaman belajar peserta didik. Pengambilan materi pembelajaran dan sumber belajar harus dipilih dengan baik, disaring, dan diselaraskan dengan tujuan pembelajaran yang ingin dicapai. Berdasarkan beberapa pendapat di atas dapat disimpulkan bahwa bahan ajar merupakan sesuatu hal yang sangat esensial dalam konteks pembelajaran. Oleh karena itu, dalam pengambilannya perlu disaring dan diselaraskan dengan tujuan pembelajaran agar dapat tercapai sesuai dengan direncanakan. Bahan ajar adalah suatu unit yang lengkap yang berdiri sendiri atas suatu rangkaian kegiatan belajar yang disusun untuk membantu peserta didik mencapai suatu tujuan yang dirumuskan secara khusus dan jelas (spesifik dan operasional) atau suatu set/program pembelajaran yang terdiri dari satu unit konsep bahan pembelajaran atau program belajar mengajar terkecil (Mahmud, 2009).

Sumber belajar adalah rujukan bahan yang digunakan untuk kegiatan pembelajaran yang berupa media cetak dan eletronik, narasumber, serta lingkungan fisik, alam, sosial, dan budaya (Wina Sanjaya, 2013: 58). Bahan atau materi pelajaran (learning materials) merupakan segala sesuatu yang menjadi isi kurikulum yang harus dikuasai oleh peserta didik sesuai dengan kompetensi dasar dalam rangka pencapaian standar kompetensi setiap bidang studi dalam satuan pendidikan tertentu (Wina Sanjaya, 2013: 141). Bahar ajar dapat dikemas dalam bentuk buku siswa, yaitu buku panduan bagi siswa dalam kegiatan pembelajaran baik dalam proses pembelajaran dalam kelas maupun di luar kelas, yang mana memuat materi pelajaran, kegiatan penyelidikan berdasarkan konsep dan informasi. Berdasarkan beberapa pendapat di atas dapat disimpulkan bahwa bahan ajar adalah suatu rangkaian kegiatan belajar mengajar yang disusun dengan lengkap untuk membantu peserta didik mencapai suatu tujuan pembelajaran yang telah dirumuskan secara spesifik dan operasional.

\section{KAJIAN TENTANG PEMBELAJARAN BATIK}

Deskripsi Mata Kuliah Tekstil berbobot 3 sks (disajikan dalam waktu 3 jam perkuliahan pada semester genap). Dalam mencapai tujuan dan manfaat mata kuliah ini, maka materi perkuliahan mencakup: konsep kriya tekstil, karakteristik, bahan dan alat kriya tekstil, berkarya tekstil teknik makrame, keterampilan berkarya batik, keterampilan berkarya tekstil teknik tapestri. Batik menurut definisi Dewan Standarisasi Tekstil Indonesia (DSTI) dan Standar Industri Indonesia (SII) (1984: 4) diuraikan bahwa batik adalah kain tekstil hasil pewarnaan, pencelupan rintang menurut corak khas ciri batik Indonesia, dengan menggunakan lilin batik sebagai zat perintang.

Batik menurut Satmawi (1979: 12), adalah seni dan cara, untuk menghias suatu kain dengan menggunakan penutup lilin atau malam untuk membentuk corak dan pola hiasnya, membentuk bidang pewarnaan, sedang warnanya itu sendiri dicelup dengan menahan zat warna. Sedangkan menurut Hamzuri (1981: 1), batik adalah lukisan atau gambar pada mori yang dibuat dengan menggunakan alat bernama 
canting. Dalam Kamus Besar Bahasa Indonesia Pusat Pembinaan dan Pengembangan Bahasa, (1997: 98) dikemukakan tentang pengertian batik, yaitu batik merupakan corak atau gambar (pada kain) yang pembuatannya secara khusus dengan menuliskan atau menerakan malam kemudian pengolahannya diproses dengan cara tertentu. Dalam Phinisi (Jurnal Pendidikan Bahasa dan Seni) yang dikemukakan oleh A. Mattaropura Husain (1992: 69), proses pembuatan batik adalah proses tutup celup. Pengertian tutup celup yaitu bagian-bagian kain ditutup dengan bahan penutup (sejenis lilin) dan mencelupkannya ke dalam warna.

Untuk mendapat gambaran yang lebih jelas, maka perlu dijelaskan pengertian seni batik dan pengembangannya. Perkataan batik berasal dari "Ambatik" (bahasa Jawa) ialah memberikan lukisan pada kain mori dengan lilin/malam, dengan memakai canting. Akar kata "Tik" adalah kata "menitik" atau "menetes". Dari pengertian-pengertian tersebut lalu orang mengartikan sebagai menulis atau menggambar yang amat teliti (Kuswadji Kawindrosusanto, 1977: 2).

Setelah dikemukakan pengertian batik dari beberapa pendapat para tokoh maka dapat ditarik kesimpulan bahwa batik ialah seni menghias dan mewarnai kain yang menggunakan teknik tutup celup. Selain dua teknik batik yang telah disebutkan di atas, teknik pembuatan batik yang paling sering dijumpai di masyarakat adalah karya batik dengan teknik ikat, teknik batik printing, dan teknik lukis. Oleh karena itu, masih banyak teknik membatik yang lain dalam memperoleh karya batik. Kata batik sebenarnya berasal dari bahasa Jawa, dari akar kata mbatik berarti ngembat titik yaitu memberikan titik-titik yang sangat banyak dan berkaitan sehingga membetuk sebuah motif (Hajar Pamadhi, 2000). Dengan pendapat di atas dapat disimpulkan bahwa kata-kata tersebut di atas mengandung arti menulis atau menggambar. Secara etimologi kata ambatik berasal dari kata tik yang berarti kecil, dapat kita artikan menulis atau menggambar serba rumit (kecil-kecil). Dengan demikian kata batik sama artinya dengan kata-menulis.

\section{METODE PENELITIAN}

Jenis penelitian ini termasuk penelitian pengembangan. Penelitian pengembangan merupakan suatu jenis penelitian yang tidak dimaksudkan untuk menguji teori akan tetapi merupakan penelitian yang berorientasi untuk menghasilkan atau mengembangkan dan memvalidasi sebuah produk. Dalam penelitian ini akan dikembangkan sebuah bahan ajar untuk mata kuliah Kriya Tekstil. Metode penelitian pengembangan yang akan dijadikan sebagai rujukan pengembangan bahan ajar dalam penelitian ini adalah menggunakan model penelitian pengembangan yang dikembangkan oleh Borg \& Gall. Ada beberapa tahapan yang dilakukan menurut Borg \& Gall (1983: 775). Teknik analisis data yang digunakan dalam penelitian ini adalah menggunakan teknik analisis deskriptif kualitatif. Prosedur penelitian yang akan dilakukan dalam penelitian ini adalah:

1. Tahap analisis kebutuhan dilakukan dengan dua kegiatan yaitu studi pustaka dan studi lapangan. Studi pustaka dilakukan untuk mengkaji dan mengumpulkan informasi tentang materi perkuliahan memerlukan bahan ajar. Selanjutnya, dilakukan melakukan wawancara terhadap beberapa mahasiswa terkait pentingnya bahan ajar pembelajaran batik. 
2. Tahap pengembangan strategi pembelajaran adalah tahap yang mana peneliti mengembangkan perencanaan pembelajaran yaitu kontrak perkuliahan. Ada beberapa hal yang dilakukan dalam pengembangan kontrak perkuliahan, yaitu: menetapkan capaian pembelajaran kuliah, menetapkan kemampuan yang diharapkan, mengembangkan materi pembelajaran, merencanakan dan mengembangkan teknik penilaian.

3. Tahap pengembangan produk, merupakan tahap pengumpulan materi pembelajaran yang terkait dengan pembelajaran tekstil (pembelajaran batik), menentukan jenis kertas dan jenis tinta yang akan digunakan, mendesain bentuk bahan ajar yang akan dikembangkan, memproduksi bahan ajar dengan cara mencetak di atas kertas yang telah ditentukan.

4. Bahan ajar tahap awal merupakan hasil cetakan pertama dari pengembangan bahan ajar yang telah dibuat atau dicetak. Selanjutnya bahan ajar yang telah dicetak akan dievaluasi dengan cara divalidasi oleh pakar atau ahli baik ahli media maupun ahli materi, kemudian dilanjutkan pada dosen tim teaching untuk mengetahui kepraktisan bahan ajar yang telah dikembangkan.

\section{HASIL DAN PEMBAHASAN}

Berdasarkan hasil penelitian yang dilakukan selama penelitian berlangsung, terdapat beberapa hal yang diperoleh yaitu kurangnya bahan ajar yang membahas tentang Seni Kriya Tekstil, dan khususnaya seni kriya batik, tenun, dan tapesri. Dengan demikian peneliti mengembangkan bahan ajar pada mata kuliah Seni Kriya Tekstil yang secara khusus memberikan pemahaman dan keterampilan kepada mahasiswa dalam pembuatan seni kriya batik. Pengembangan bahan ajar yang telah dilakukan melalui beberapa tahap, yaitu dimulai dari tahap analisis kebutuhan, mengembangkan strategi pembelajaran, mengembangkan bahan ajar, sampai dengan realisasi bahan ajar tahap awal. Bahan ajar yang telah dikembangkan merupakan draft bahan ajar pada mata kuliah Seni Kriya Tekstil untuk mahasiswa Program Studi Pendidikan Seni Rupa Fakultas Seni dan Desain Universitas Negeri Makassar. Bahan ajar yang dikembangkan belum dilakukan tahap validasi dan ujicoba pada mahasiswa sebagai pengguna bahan ajar yang dikembangkan.

Tahap analisis kebutuhan yang dilakukan pada pengembangan bahan ajar seni kriya tekstil adalah melalui dua tahap yaitu, tahap studi lapangan dan tahap studi literatur atau studi pustaka. Studi pustaka dilakukan dengan cara mengkaji kurikulum yaitu menganalisis capaian kompetensi mata kuliah seni kriya tekstil serta mengumpulkan informasi terkait tentang materi seni kriya tekstil. Peneliti menganalisis capaian kompetensi dan learning outcome mata kuliah seni kriya tekstil. Selain itu, peneliti mengkaji buku-buku literatur yang dijadikan sebagai sumber rujukan yang selama ini digunakan pada mata kuliah seni kriya tekstil dan buku literatur yang tersedia di perpustakaan Fakultas Seni dan Desain Universitas Negeri Makassar. Tahap ini dilakukan guna memperoleh data yang akurat tentang materi Seni Kriya Tekstil yang dapat dijadikan sebagai salah satu sumber bahan ajar atau sumber rujukan mahasiswa dalam melakukan proses perkuliahan.

Tahap studi lapangan atau tahap observasi dilakukan dengan mengamati secara langsung pelaksanaan perkuliahan seni kriya tekstil, yang mana, pada saat perkuliahan berlangsung peneliti bersama tim teaching melaksanakan perkuliahan 
dengan menggunakan media yaitu tampilan slide power point. Referensi atau sumber rujukan dalam pembelajaran kriya tekstil masih terbatas. Dalam hal ini peneliti sebagai dosen pengampu mata kuliah seni kriya tekstil dan tim teaching dengan ibu Aulia Evawani Nurdin, S. Pd., M. Pd., mengharapkan adanya bahan ajar yang dapat dijadikan sebagai sumber bacaan dan rujukan oleh mahasiswa di Program Studi Pendidikan Studi Pendidikan Seni Rupa Fakultas Seni dan Desain Universitas Negeri Makassar, agar hasil perkuliahan dapat terlaksana sesuai dengan capaian outcome yang telah dirumuskan dalam Rencana Program Semester (RPS) yang telah dikembangkan.

Selanjutnya, dengan adanya bahan ajar yang dikembangkan dapat mengatasi permasalahan mahasiswa, khususnya rendahnya pemahaman mahasiswa dan kurangnya kreativitas mahasiswa dalam membuat desain motif batik dapat diatas. Hal ini sesuai dengan temuan penelitian yang dilakukan oleh mahasiswa Program Studi Pendidikan Seni Rupa FSD UNM angkatan 2011 yaitu Muhammad Arif pada tahun 2017. Hasil penelitiannya diketahui bahwa salah satu faktor yang mempengaruhi rendahnya kreativitas mahasiswa angakatan 2015 Program Studi Pendididkan Seni Rupa dalam membuat desain motif batik adalah karena kurangnya referensi atau sumber bacaan mahasiswa terkait dengan perkualiahan seni kriya tekstil pada umumnya dan khususnya pembelajaran batik.

Bahan ajar seni kriya tekstil yang selama ini digunakan masih sangat minim, khususnya dalam pembelajaran seni kriya batik. Dengan demikian mahasiswa kurang memiliki referensi tentang desain motif batif yang maengakibatkan mahasiswa kurang kreatif dalam membuat desain motif batik pada mata kuliah seni kriya tekstil. Oleh karena itu, peneliti sebagai dosen pengampu mata kuliah bersama tim teaching mengembangkan bahan ajar seni kriya tekstil guna menambah referensi perkuliahan seni kriya tekstil dan dapat mengatasi berbagai permasalahan yang ada. Pengembangan strategi pembelajaran melalui beberapa tahap yaitu mulai dari menentukan capaian pembelajaran lulusan yang dibebankan pada matakuliah, menentukan kemampuan yang diharapkan, menentukan bahan kajian, menetapkan waktu yang digunakan, menentukan pengalaman belajar mahasiswa, menentukan kriteria atau indikator ketercapaian dalam pembelajaran, dan menetapkan bobot dari setiap kemampuan yang diharapkan.

Pengembangan strategi yang dilakukan disesuaikan dengan ungkapan Ibrahim dalam Jamil Suprihatiningrum (2016: 133) bahwa dalam mengembangkan perangkat pembelajaran terdiri dari beberapa langkah yaitu: perlu memperhatikan tujuan pembelajaran, karakter siswa, materi, penilaian awal siswa, aktivitas belajar mengajar dan sumber belajar, pelayanan pendukung, evaluasi dan revisi. Strategi pembelajaran yang dikembangkan sesuai dengan pendapat Wina Sanjaya (2013: 4045) bahwa penyusunan strategi pembelajaran berdasarkan komponen-komponen dalam sistem pembelajaran, kemudian ditentukan langkah-langkah dalam menyusun perencanaan pembelajaran. Adapun langkah-langkah dalam menyusun perencanaan pembelajaran yaitu: merumuskan tujuan khusus, pengalaman belajar, kegiatan belajar mengajar, orang-orang yang terlibat, bahan dan alat, fasilitas fisik, dan perencanaan evaluasi dan pengembangan. Dalam pengembangan bahan ajar untuk mata kuliah seni kriya keramik dilakukan perumusan tujuan pembelajaran 
yang dirancang berdasarkan tuntutan atas kompetensi sumber daya manusia yang standar dari lulusan Perguruan Tinggi (PT) yaitu Kerangka Kualifikasi Nasional Indonesia (KKNI).

Rumusan tujuan pembelajaran yang mana dalam Kerangka Kualifikasi Nasional Indonesia (KKNI) merupakan capaian pembelajaran (learning outcomes). Rumusan capaian pembelajaran ini disusun dalam 4 unsur yaitu sikap dan tata nilai, kemampuan kerja, penguasaan pengetahuan, dan wewenang dan tanggung jawab. Capaian pembelajaran lulusan yang dibebankan pada mata kuliah ini adalah memahami konsep kriya tekstil berupa makrame, batik, dan tapestri, serta mewujudkan karya dengan mengaplikasikan teknik makrame, batik, dan tapestri. Mata kuliah ini menekankan pada penguasaan bahan, alat, dan teknik. Materi perkuliahan mencakup jenis bahan, karakteristik bahan, kegunaan bahan, jenis alat, fungsi alat, teknik makrame, batik, tapestri. Kegiatan belajar mengajar dilaksanakan dengan perkuliahan teori dan praktik. Evaluasi dilakukan dengan tugas portofolio, yaitu karya-karya pada tugas harian bersama laporan konsep dan proses pembuatan karya dikumpulkan pada akhir semester dan dilanjutkan dengan presentasi karya.

Untuk mengetahui kevalidan, kepraktisan, dan keefektifan bahan ajar yang dikembangkan, maka peneliti mengaharapkan adanya penelitian lanjutan dari bahan ajar yang dikembangkan. Dengan adanya evaluasi ahli baik ahli materi maupun ahli media dan mahasiswa sebagai pengguna bahan ajar, maka bahan ajar yang dikembangkan dapat diketahui kevalidan, kepraktisan dan keefektivannya. Dengan demikian, dapat digunakan dengan baik oleh mahasiswa khususnya mahasiswa di Program Studi Pendidikan Seni Rupa Fakultas Seni dan Desain Universitas Negeri Makassar dan mahasiswa Program Studi Seni pada umumnya.

\section{KESIMPULAN}

Berdasarkan hasil yang telah dicapai dan dikemukakan pada bagian sebelumnya, kesimpulan yang diuraikan pada bagian ini merupakan hasil penelitian berupa bahan ajar Seni Kriya Tekstil. Adapun kesimpulan hasil penelitian yang telah dicapai adalah: pengembangan bahan ajar pada mata kuliah Seni Kriya Tekstil melalui beberapa tahap, yaitu: tahap analisis kebutuhan melalui dua tahap yaitu tahap studi lapangan dan studi literatur, tahap pengembangan strategi pembelajaran melalui pengkajian rencana program semester, tahap pengembangaan bahan ajar yaitu mengumpulkan materi-materi terkjait dengan seni kriya tesktil, dan realisasi bahan ajar tahap awal. Bahan ajar yang dikembangkan disesuaikan dengan Rencana Program Semester (RPS) yang telah dikembangkan sebelumnya. Bahan ajar yang dikembangkan belum dilakukan tahap eavaluasi ahli baik ahli materi, ahli media maupun ujicoba.

\section{DAFTAR PUSTAKA}

Ali, Lukman. (1991). Kamus Besar Bahasa Indonesia. Jakarta: Balai Pustaka Depdikbud.

AArikunto, Suharsimi. (1990). Pengelolaan Kelas dan Siswa (Sebuah Pendekatan Evaluatif., Jakarta: CV. Rajawali.

Djamarah, Syaiful Bahri. (1997). Guru dan Anak Didik dalam Interasi Edukatif. Jakarta: Rineka Cipta. 
Mahmud. (2009). Pembelajaran Modul. (http://mahmudogkumpulanmakalah.blogspot.com/2011/01/pembelajaran-modul.html). di akses pada t anggal 12 April 2014.

Permendiknas. (2007). Standar Penilaian Pendidikan. Jakarta: CV Novindo Pustaka Mandiri.

Sanjaya, Wina. (2013). Perencanaan dan Desain Sistem Pemblajaran. Jakarta: Kencana Prenadamedia Group.

Sobandi, Bandi. (2008). Model Pembelajaran Kritik dan Apresiasi Seni Rupa. Solo: Maulana Offset.

Winkel. (2009). Psikologi Pengajaran. Yogyakarta: Media Abadi.

Yulaelawati, Ella. (2004). Kurikulum dan Pembelajaran Filosofi Teori dan Aplikasi. Bandung: Pakar Raya. 